\title{
Media Branding and Brand Management: Promotion Strategies of Ukrainian National TV Channels during COVID-19 Pandemic
}

\author{
Tetiana Shalman ${ }^{1 *}$ \\ Vitalii Kornieiev ${ }^{1}$ \\ Nadiia Bilan ${ }^{1}$ \\ Tetiana Glushkova ${ }^{1}$ \\ Alla Bashuk ${ }^{1}$ \\ Margaryta Netreba ${ }^{2}$ \\ ${ }^{1}$ Taras Shevchenko National University of Kyiv, \\ Volodymyrska Str, 6o, Kyiv, o1033, \\ Ukraine \\ ${ }^{2}$ Borys Grinchenko Kyiv University, \\ Bulvarno-Kudriavska Str, 18/2, \\ Kyiv, 04053, Ukraine \\ ${ }^{*}$ Corresponding Author
}

DOI: https://doi.org/10.36941/ajis-2022-0031

\section{Abstract}

The research explores the Ukrainian TV market, where major TV channels are owned by the four large media groups and are marked by peculiar branding and promotional activities. It is their branding and promotion strategies during the coronavirus pandemic that the article focuses on. To achieve this, the authors employ a systematic analysis to a sample of the leading Ukrainian channels' broadcasting as well as to examine, in particular, their branded programs and their extensions on digital platforms launched by the media channels in order to facilitate their communication with audiences. The research reveals similarities in the channels' promotion activities and practices of branding, common to TV industry in general. These include integrated marketing activities and branding strategies such as audience-oriented content, cross/self-promotion, new value chains, communicative engagement, sponsorships/partnerships and public relations.

Keywords: media, marketing activity, branding strategy, TV, Ukraine, COVID-19

\section{Introduction}

The emergence of technologically mediated communication and its rapid development from the 1990 on onwards have enhanced multiple production and distribution in the media market making it congested with the ever-growing number of media outlets. In this increasingly fierce environment, media companies are forced to search for new adaptation forms: novel strategies of brand 
management and promotion, untapped resources and skills, breakthrough management practices of brand production and distribution.

As the media market is moved from "low to high choice" environment (Nielsen, Cornia \& Kalogeropoulos, 2016, p. 1) and enhanced by the Internet, media companies find themselves facing an environment characterized by "distributed discovery", where audiences can choose from a wide range of broadcasting channels, print media, websites, social media and, recently, mobile apps and alerts (Nielsen et al., 2016, p. 12). This makes media outlets shift from mono-traditional brand promotion to multi-format mobile brand management that employs a variety of brand-promoting strategies.

The intensified competition in the media market worldwide, to which Ukraine is a part, implies complementary diversification of media outlets' promotion strategies aimed at image building in the arena which incessantly engenders more media alternatives.

The coronavirus pandemic has impacted all sectors: it has altered functioning of educational institutions (Makki \& Bali, 2021); it has shaken strongly tourist business (Dimitrios, Christos, Ioannis, \& Vasiliadis, 2020; Fernández-Bedoya, Meneses-La-Riva, \& Suyo-Vega, 2021; Ocheni, Agba, Agba, \& Eteng, 2020); it has forced state officials to reconsider state-governing practices (Machmud, Irawan, Karinda, Susilo, \& Salahudin, 2021) as well as to review issues related to human rights (Rusi \& Shqarri, 2020); it has kept in limbo show business and made celebrities look for alternative channels to maintain contact with their audiences (Chaiuk, Alyeksyeyeva, Borysovych, Karpova, \& Gayevska, 2021). This study explores branding and brand management strategies employed by Ukrainian media companies in the national media market hit by the COVID-19 pandemic. The results of the study will offer an insight into the Ukrainian media market, its adaptation to today's market and the application of modern branding theories in management practices and processes by Ukrainian media. Hence, the study will contribute to the growing publications on Ukrainian media landscape, which is endowed with peculiar features that have not yet received due attention from researchers.

\section{Literature Review}

\subsection{Media branding and brand management: theory and definition}

According to Russ-Mohl and Nazhdiminova (2015, p. 346), "[t]he media have, for decades, covered everything except themselves": the media industry traditionally acted as a vehicle to promote their advertisers' brands, while promoting themselves was limited to producing quality journalistic and/or entertainment content to reach audiences (Calder \& Malthouse, 2008, p. 89). However, in recent decades, i.e., after the 1990s' technological leap and the arrival of the Internet, production processes of media markets have altered structurally (Nielson, 2016) and media industries have started to embrace branding and brand management (McDowell, $2006 \mathrm{~b}$ ). Technological innovations have brought about multicasting and multiple distribution outlets making numerous services and products available for the audiences (Chan-Olmsted, 2006; Schultz, Block, \& Viswanathan, 2014). This has intensified the competition, made the media market more complex and increased the level of audience's instability (McDowell, 2011; Ots \& Wolff, 2008, p. 100). As a result, media companies, products and contents have to differentiate themselves by brand management (Siegert, 2008). This, combined with the aforementioned factors, forces them to adopt the brand management as "a managerial tool" to keep "their most important assets - their users" (Ots, 2008, p. 2).

'Media brand' has been for long a field of research with the increasing number of publications (see, for example, (Aaker, 1991, 2010; Chan-Olmsted 2006, 2011; McDowell 2006, 2011; Chang \& ChanOlmsted, 2010; Dahlen \& Smith 2010; Siegert 2008, Siegert et al. 2015)). Exploring 'media brand' from different perspectives makes it an object of an interdisciplinary research that involves such areas as marketing and economic management (e.g., (Keller, 2003; Burmann \& Zeplin, 2005; Picard, 2005; McDowell, 2006; Doyle, 2012; Siegert \& von Rimscha, 2013)), marketing and social psychology with its focus on audience, the brand-to-user relationship and identity belonging (McDowell, 20o6; Gerth, 2010; Siegert et al., 2015), sociology and media studies (see (McQuail, 1992; Picard, 2004)). 
Defining the media brand is a continuous debate between scholars studying marketing, communication and public relations (McDowell, 2006 a). McDowell (2006 b, p. 234) views brand as "a name, term, sign, design, or unifying combination of them intended to identify and distinguish a product or service from its competitors". Calder and Malthouse, in their turn, conceptualize brand from the market and consumer perspective as "a promise to the consumer, a value proposition, a positioning in the consumer's mind, a big idea" (Calder \& Malthouse, 2008, p. 89). The latter definition agrees with that of Siegert, Förster, Chan-Olmsted and Ots (2015, p. 1) who draw on the audience's psycho-cognitive perspective: a brand is interpreted as "a construct carrying all the connotations of the audience in terms of the emotional, stylistic, cognitive, unconscious or conscious significations".

Media brands integrate with the concept of brand hierarchies, i.e., different brands at different levels of the same company. Hence, brands are not arbitrary or "one-hit wonders" but, rather, a systematically institutionalized activity which "refers to different levels in a media brand's architecture"; the activity may include the corporate or the channel brand and some other subbrands like a show or some other different genre (Siegert et al., 2015, p. 1). Considering the mentioned above and following the definition of brand by Burmann and Zeplin (2005) and Keller (2013), brand may be more generally understood as a package of advantages with specific contributions that differentiate it from other packages pursuing the fulfillment of the same goal in the same target group.

\subsection{The purpose and the process of media brand management}

According to Keller (2013, p. 69), "the power of a brand lies in what resides in the minds and hearts of customers". This makes branding a communication process of extreme importance without which "a company cannot create points-of-parity and points-of-difference - the brand does not exist in the minds of the consumer" (Siegert, 2008, p.13). Yet, it should be noted that branding is not an exclusive prerogative of commercial organizations. The non-profit sector as well as local authorities have proved to be well-aware of the beneficial effect a successful branding strategy may entail (see, for example, (Hasaj \& Krymbi, 2013; Moroz, Karachyna, Vakar, \& Vitiuk, 2020)). Interestingly, branding does not lead only to the consumer's loyalty: research reveals the significant impact of an organization's brand on personnel retention (Mostafa, El-Borsaly, Hafez, \& Hassan, 2021).

According to Siegert (2008, p.12), media industry branding has three goals: "brand effects, brand differentiation and brand value". To accomplish these goals, brand identity and brand image must be well interconnected. Through brands, media industry attempts "to build strong and long-lasting bonds with their audiences - to connect to existing and potential viewers, listeners or readers in ways that are relevant and unique" (Ots, 2008, p. 2). Hence, the task of media brand management is to create rewarding associations in the audience so as to bring out a competitive advantage for these brands (Fournier, 1998; Siegert et al., 2015) and to build what Bourdieu (1986) calls audiences' "cultural capital" and, consequently, a consumer identity belonging to the brand.

Thus, brand management is a process of communicating the audience's thoughts and feelings to create and enhance a brand value beyond the product's functional advantage or worthiness (McDowell, $2006 \mathrm{~b}$ ). In this context, media branding works as a strategy to differentiate a company or a product from that of a competitor (Aaker, 2010; Keller, 2013), "show a close link to competence, credibility and quality" so that "brands contribute to the value of a company" (Siegert, 2008, p. 11). This differentiation actualized by brands creates a specific quality and credibility; it builds an identity and position of the product, which makes branding a common strategy for media industry (McDowell, 2005; Siegert, 2008, p. 11; Ots \& Wolff, 2008, p. 100). Since the media market is a twosided market that combines a consumer market (audience) and a business market (advertisers or media buyers) (McDowell, 2006 a; Siegert, 2008; Sommer, 2015; Sommer \& Marty, 2015), media companies have to build brand strategies for both of the markets (Ots \& Wolff, 2008, p. 99).

However, in times of diversity, technological convergence, fragmentation of audiences and 
multiplicity of their choices, the challenge is not only to create a brand but, rather, to make this brand competitive enough to reach the largest share of the market. Hence, building the brand's position, identity belonging with the audience and, finally, brand loyalty is an extra concern of media promotion. To make a brand powerful and competitive as well as to enhance brand loyalty, a media firm needs "to develop customer engagement with products and services" (Malthouse \& Schultz, 2014, p. 239), which cannot be successfully implemented without an effective application of brand management and its components. Riezebos, Kist, and Kootstra (2002) identify two motives to adopt brand strategies: (a) competitive motive that differentiates the brand from those of competitors by emphasizing its uniqueness, and (b) motive of adding value to the offered product or service beyond its functional use which helps to enhance the customer's associations with the brand.

In brand management, a brand consists of: (1) media brand identity defined as a "unique set of brand associations that the brand strategist aspires to create or maintain. These associations represent what the brand stands for and imply promises to the customers from the organization" (Aaker, 2010, p. 68); (2) media brand equity is named by (McDowell 2006a, p. 10) "holy grail of brand management" because it enhances the efficiency and effectiveness of marketing performance and, thus, leads to behavioral loyalty of the customer (Hoeffler \& Keller, 2003; McDowell \& Sutherland, 200o).

Media brand equity, in turn, includes: (a) media brand awareness which is developed when "the external stakeholders are aware of the brand" and this makes it "a prerequisite of the brand image" but not part of it (Burmann, Piehler \& Löwa, 2015, p. 221), and (b) a brand image, which is defined as "a multidimensional construct that consists of attitudes toward a brand" (ibid.) and includes (i) brand attributes (descriptive features of a brand); (ii) functional brand benefits (outcome of operational characteristics of a brand), and (iii) symbolic brand benefits (prestige) (ibid.) (see Figure 1).

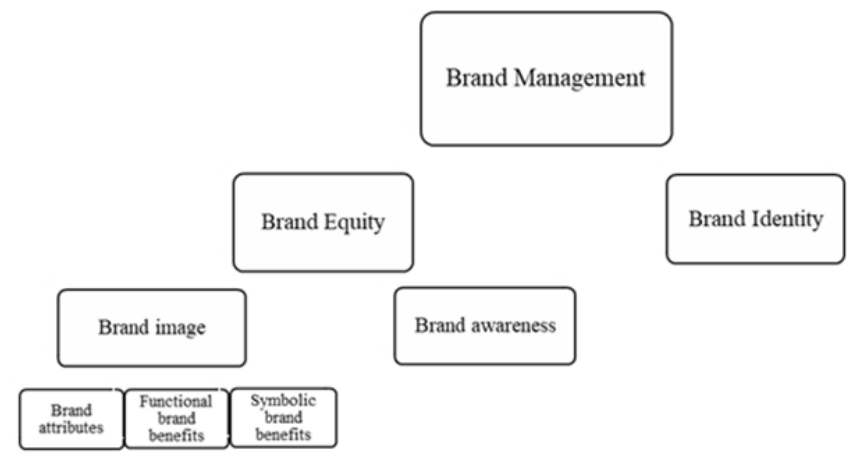

Figure 1: Brand management and its components

The communication process of a brand with its audience entails promoting strategies that make the recipients perceive the brand positively and turn them into loyal users. Weinacht (2015, p. 232) outlines the following components of general communication management: (a) strategy which consists of "goals, positioning, style, a message", and (b) activities that include "target groups, platforms, instruments" as well as such resources as "time, budget, staff". Moreover, in his systematic review of literature on media brands and their marketing communication, Weinacht (2015, p. 234) summarizes the descriptive characteristics of media brand promotion strategies, their typologies, goals and techniques as outlined in Table 1 :

Table 1: Goals of media brand communication (Weinacht, 2015, p. 234).

\begin{tabular}{|l|l|l|}
\hline Type & Goal & Techniques \\
\hline Cognitive & Brand awareness & Naming and explaining media brands \\
\hline Affective & Brand image & $\begin{array}{l}\text { Use of trailer/teaser, corporate design, staff and contexts of } \\
\text { editorial content on media brands }\end{array}$ \\
\hline
\end{tabular}




\begin{tabular}{|l|l|l|}
\hline Conative & $\begin{array}{l}\text { Brand loyalty, brand } \\
\text { commitment, brand trial }\end{array}$ & $\begin{array}{l}\text { Reflective communication in other media and services such as } \\
\text { program sheets, teasers etc. }\end{array}$ \\
\hline
\end{tabular}

Burmann et al. (2015), in their turn, distinguish three steps for the brand management process. The first step is strategic brand management, the second one is operational brand management, and third step is brand controlling (p. 223) (see Figure 2).

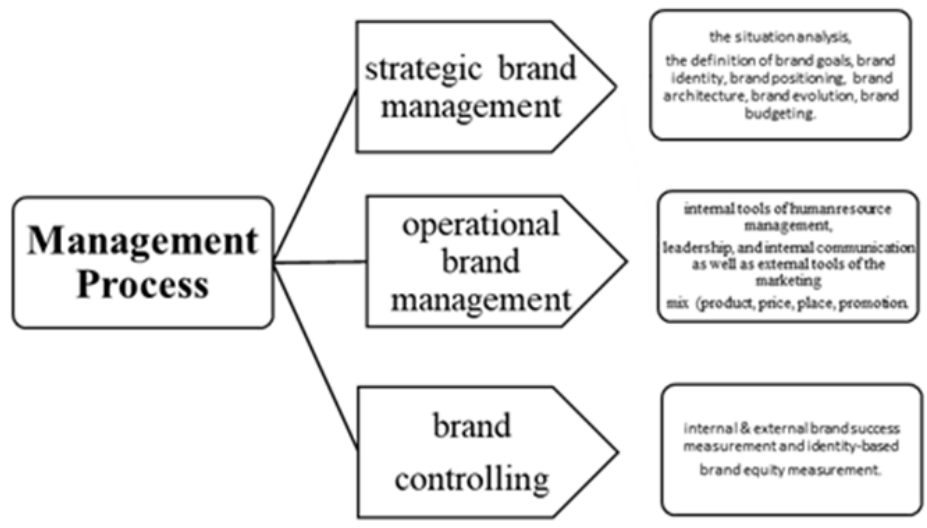

Figure 2: Brand Management Process

\subsection{Understanding the Ukrainian market}

It should be noted that the Ukrainian media market is not a typical market, at least compared to those in the West, as it is still experiencing the influence of the Soviet era where, after Ukraine proclaimed its independence, the leading media outlets have been controlled by politically powerful elites. Nowadays, this system has evolved into a media industry controlled by the oligarchs. This peculiar feature is pointed out by numerous researchers (see (Andrusieczko, 2019; Ivanov, 2019; Budivska \& Orlova 2017; Ryabinska, 2011)). According to Nikitina (2020 p. 188), the media landscape in Ukraine has destroyed the state monopoly and the Ukrainian media system has travelled from "total control" to "pluralism". However, this pluralism is still "limited" because it cannot destroy the oligarchic control which "captures" the media landscape in Ukraine (Nikitina, 2020, p. 168, 188). The leading Ukrainian media groups "are politics-driven rather than market-driven" (ibid., p. 193). In other words, they are not either business-making or profit-oriented: they are used for political influence, therefore most of these media outlets operate at loss and the owners are funding them (Albrecht, 2019).

Thus, since " $75 \%$ of Ukrainian media belong to oligarchs and politicians" (Andrusieczko, 2019, p. 9), the Ukrainian media market can be characterized as an "oligopolistic" market where a small number of media companies compete for maximizing their reach. Although "this system limits the real competition and rivalry in Ukraine and leads to many distortions in various spheres" (Andrusieczko, 2019, p. 9), oligopolistic markets "have become more competitive with more and more companies trying to capture the audience's attention" (Müller, 2017, p. 71). However, to exclude politicized media run by oligarchs, many media outlets in Ukraine depend exclusively on advertisements for making money (Albrecht, 2019). Consequently, whether aiming at profiting, which is less expected with the largest media groups, or using them for their influence on the political, social or economic scene of the country (Albrecht, 2019; Nikitina, 2020), these media outlets still have to build and strengthen competitive brands to attract audiences and enlarge their share of the Ukrainian media market as "the media are still indispensable for building brand awareness and brand knowledge” (Siegert, 2008, p. 14).

The data on the Ukrainian TV media market shows that Ukraine has 214 TV channels. This 
includes 28 national television broadcasters, 76 regional television broadcasters, and 110 satellite television channels (National Council of Television and Radio Broadcasting of Ukraine, n.d.). Though TV consumption tends to decrease among different groups of Ukrainian audiences in favor of internet use (see Figure 3 and also (Nikitina, 2020, p. 189)), still TV is the most popular mass media channel in Ukraine (Nikitina, 2020; Ivanov, 2019; Andrusieczko, 2019).

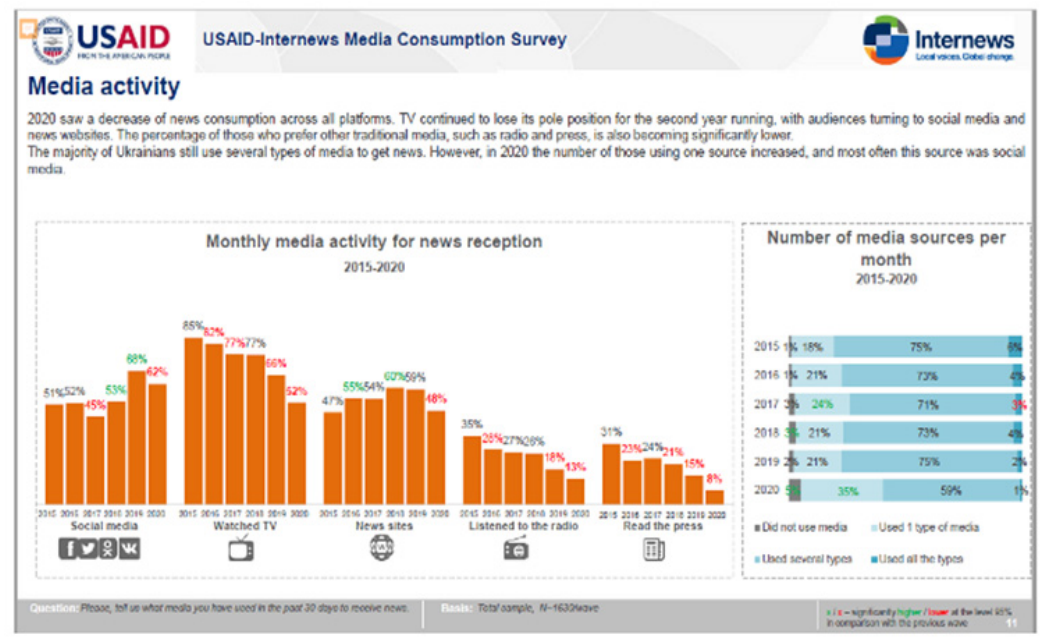

Figure 3: Ratings of National Media Consumption in Ukraine 2015- 2020 (Source: USAID-Internews)

All the top TV channels in Ukraine (see Figure 4) as well as many other TV channels belong to the four leading media conglomerates: Media Group Ukraine (TV Channel Ukraine); 1+1 Media Group (TV channels: 1+1, TET, 2+2); Inter Media Group (TV channels: Inter, NTN, Enter film), and Starlight Media (TV channels: ICTV, STB, Novyi Kanal (New Channel)). All these private commercial channels are leaders of the Ukrainian TV market that only alternate their positions in the national top 1o TV channels rating (see Figures 4 and 5).

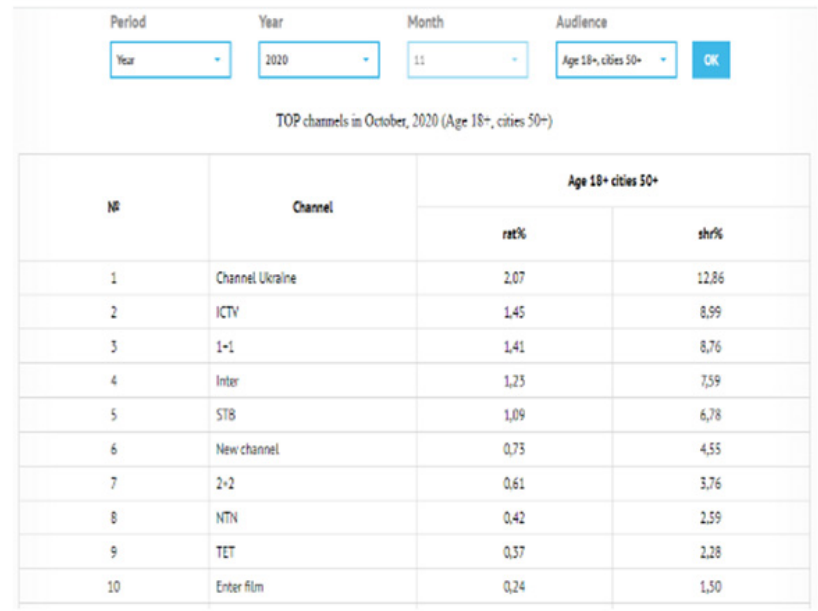

Figure 4: Top TV channels in Ukraine, 2020 (age 18+, cities 50+). (Source: Television Industry Committee) 


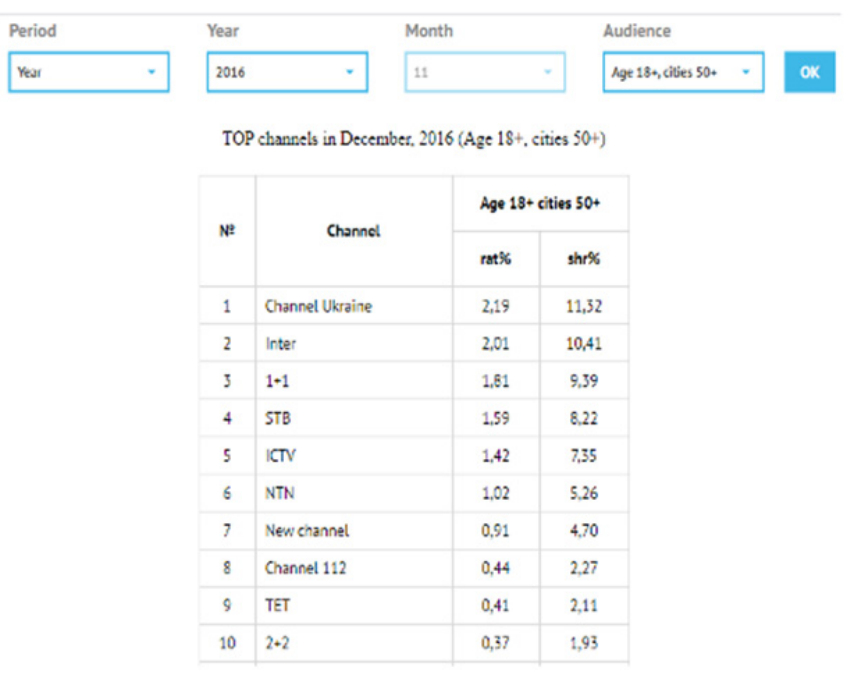

Figure 5: Top TV channels in Ukraine, 2016 (age 18+, cities 50+). (Source: Television Industry Committee)

Due to space limitations, the article focuses on national TV-broadcasting, the biggest and most developed medium that dominates the Ukrainian media industry to the extent that the Ukrainians have been called a "TV-viewing nation" (Ryabinska, 2011, p. 5). Besides, in Ukraine, promotion and brand management practices tend to be initiated in the TV sphere and followed by other media because, generally speaking, all media employ relatively identical set of promotion and brand management strategies and techniques.

\section{Methodology}

The purpose of this article is to study the Ukrainian TV strategies of self-branding and selfpromotion. The research is a systematic analysis of seven leading TV channels in Ukraine (Kanal Ukraina (Channel Ukraine), 1+1, TET, Inter, ICTV, STB, Novyi Kanal (New Channel)). The material of the research is a 230-hour continuous sampling within the period of September - November 2020 as well as archive materials that helped to evaluate the channels' response to the 2020 emergencies: COVID-19 pandemic, quarantine and lockdown. The data have been broken down into the strategies, means and practices implemented by the channels to promote themselves and to keep up with the social changes. The next stage of the research is the analysis of the channels' extensions on websites, social media and other platforms, followed by a qualitative analysis of specific branded programs as well as techniques used to enhance their consumers' engagement. The results are shown and discussed on the basis of the theoretical background of branding and brand theories discussed above.

\section{Findings and Discussion}

The research has revealed similarities and standardized use of branding strategies and brandmanagement practices employed by Ukrainian media groups. The similarities are found in marketing means, production methods and processes, broadcasting models and modes of programs, platforms of distribution, consumers' engagement and interaction. The noticeable difference is only at the level of intensity in the use of brand management practices and promotion tools. Hence, all the investigated TV channels in Ukraine share branding and promotion strategies such as: creating an 
integrated content, cross-promotion, brand extension (value chain), self-promotion, engagement and interactive communication with audiences, public relations, partnerships or sponsorships, and some investments.

One of the strategies most popular with the leading TV channels in Ukraine is integrating content that matches the audience's interest and orienting this content to meet their experiences and to cater their taste. The aim is to develop a consumer-experience-based brand that, with continuous updates, is always relevant to the audience's experience, which leads to building an identity relationship in consumers who develop loyalty to the brand. According to Gentzkow \& Shapiro (2008, p. 144), the first important category of a demand-driven bias comes from the consumers' apparent preference for sources that confirm their prior beliefs. The delivered content aims at meeting consumers' needs and it is therefore integrated with all what the audience may be interested in. Thus, in their content marketing strategies, Ukrainian TV companies target mass audience with informative, entertaining and/or educational content and attempt to avoid audiences' reactance. This is achieved by localizing the content, i.e., by creating a content unique to the local audience, which is achieved by adopting a familiar studio design, including local pictures or cast as well as by modulating culturally-proximate content and avoiding elements that might not be appreciated by the audiences (Rohn, 2015, p. 88).

According to Nikitina (2020, p. 191), Ukrainian television audience share a common feature that is the wish "to dive into the marvelous world of shows" as a reaction to their problems such as poverty, war, uncertainty about their future. In other words, Ukrainian TV viewers tend to "escape from reality" by watching entertainment TV. Therefore, among the most popular programs in the portfolio of Ukrainian TV channels, we can find programs such as reality shows (e.g., Ukrainian Super Top Model (Novyi Kanal), Super Mom, The Bachelor, and The Chef (STB), Wife Swap and Blind Wedding (1+1)); series and movies (e.g., Relatives and \#School (1+1), Challenge (Channel Ukraina), EuroCEO (TET)); entertainment (e.g., Dances with Stars, Voice of the Country and Make a Dream Come True (1+1), Fiancee for Dad and X-Factor (STB)). In addition, there are some other, informative and political talk shows with fewer viewers such as The Right to Power $(1+1)$, Freedom of Speech (ICTV), Ukraine is on Air, High-Profile Case (Channel Ukraina)) as well as comedy sitcoms (The Party, The Alien (TET), Frozen (1+1)) and educational shows (Scrutinizing the Party's Papers (Channel Ukraina), Lives of Famous People (1+1)).

However, considering the fact that media are always in "struggle to keep up with the tides of attention" (Müller, 2017, p. 71), branded content is not the channels' interminable trademark but, rather, a variable and replaceable feature influenced by ever-changing conditions. Thus, they inevitably display the tendency for "slanting toward consumers' priors" (Gentzkow \& Shapiro, 2008, p. 144). During the Covid-19 pandemic in 2020, Ukrainian TV channels started adapting their content to the new situation and quarantine circumstances: the TV channels focused more on informative and educational coronavirus-related stories and balanced them with entertaining tips on how to cope with social, psychological and economic challenges of the pandemic. So, Channel Ukraina, for example, set going the \#ukrainaathome (Ukraine at home) flash mob, inviting ordinary viewers to join celebrities talking about useful activities during the lockdown. STB, in its turn, launched a live Instagram marathon of interesting conversations and quarantine tips from the stars of this TV channel. To keep their audience entertained and engaged during the marathon, the channel launched a special project \#tatonakarantini (Ukr. dad on quarantine) with Dmitry Karpachev who stands as brand for the channel by himself. The famous host talked live to celebrity dads on the official STB Instagram account about their quarantine experience as full-time fathers.

Moreover, in cooperation with the Ukrainian Ministry of Education and Science, STB, $1+1$, Novyi Kanal, Inter, ICTV and Channel Ukraina launched the all-Ukrainian school online project: video

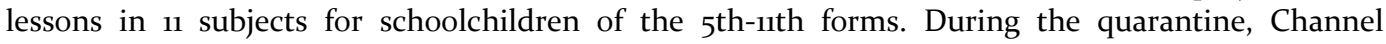
Ukraina also started \#UkraineHome and \#Coronavirus campaigns on air and on digital platforms.

Marketing of integrated content is driven by market consumption and communication with the audience rather than media ethics or quality norms. Nevertheless, delivering a content based on 
consumer experience is the most effective branding management practice of media, which allows (Chan-Olmsted \& Shay, 2015, p. 21) to say that "integrated content is king".

Branded content of TV channels is delivered through multiple platforms at different times. This creates more brand touchpoints and ensures more responsiveness to consumers' needs though their unpredictable behavior and their consumption are not platform/outlet dependent (Calder \& Malthouse, 2008; Chan-Olmsted, 2011; Chan-Olmsted \& Shay 2015; Jenkins, 2008; Thompson \& Strutton, 2012). This brand extension strategy increases the life span of the product and extends its interactivity to digital media and mobile services such as text messaging and apps under the same brand. This is an implication of what Chan-Olmsted and Shay $(2015$, p. 17) call "the new value chain" or the "long tail phenomenon". According to the scholars, by implementing such a strategy, the brand's image, relationship and loyalty are ensured by meeting the users at any place they want to choose from and consume their content (ibid.). Hence, Ukrainian TV channels extend their brands to the digital arena to enhance their competitiveness not only by having their internet websites and YouTube channels (Novyi Kanal is the first TV channel in Ukraine to earn the golden YouTube button), but also by being active on such popular social media as Facebook, Twitter, Instagram and Telegram. By broadcasting their content on the social media, TV channels maximize their reach to all possible audiences. Interestingly, it is their popular programs, sub-brands by themselves, that the channels develop pages or online sites for. By doing so, they promote their brands and sub-brands and gain extra audiences who are stamped with volatile loyalty, i.e., these are consumers that might not be interested in the full package but rather in specific programs or shows on the channel. By giving the programs their own self-sustaining brand on different platforms, they help to get these reluctant audiences hooked to choose their favorite content and consume it, which builds the brand - consumer relationship and strengthens brand loyalty.

Another example of the brand extension strategy is the $1+1$ video app launched by $1+1$ Media Group, the owner of ten media outlets (eight TV channels and two news agencies). The Group repackaged its media contents into the app which can be downloaded on computers and mobile phones. The app includes all media outlets of the Group (information, entertainment, sports, news) and users are invited to choose their favorite channel, genre, or a particular program and to get access to them including their archives (see Figure 6)

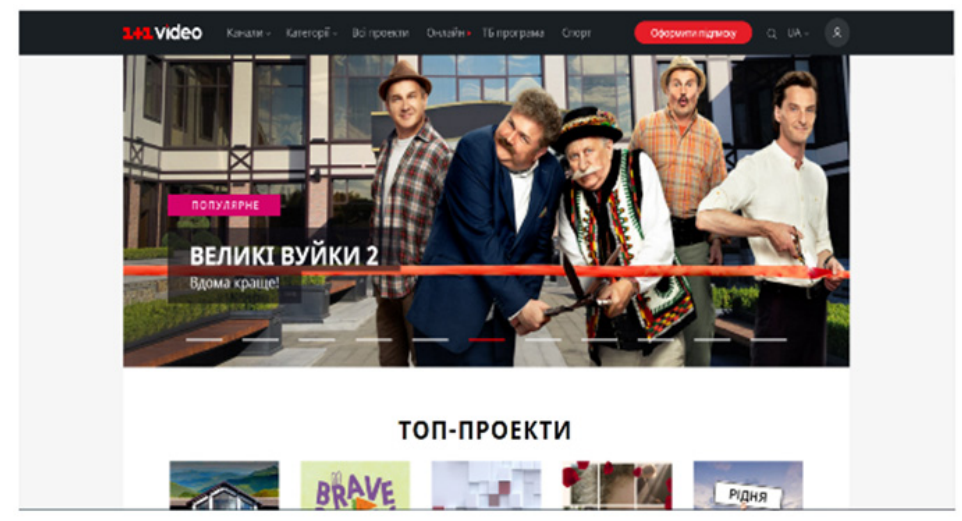

Figure 6: 1+1 video app launched by 1+1 Media Group.

Besides, TV channels do not only promote their popular programs as sub-brands, which enhances the promotion of the channel and, in the long run, of the entire media group, but they also use branded programs as communication channels with their audience and thus boost the efficiency of this interaction. This engagement mechanism enhances the relationship between media brands and 
consumers. Eventually, the mechanism results in constructing consumers' long-term emotional investment (Chan-Olmsted \& Shay, 2015, p. 14). Ukrainian TV channels effectively employ interactive communication and engagement with the consumer, another indispensable branding and promotion strategy in the digital time. The effective presence of Ukrainian TV channels on all possible digital platforms, notably social media that are gaining popularity in Ukraine, allows the users to discover and engage with their favorite content/programs.

In doing so, shows create an "idol" for the audiences, which sends a persuasive call for them to get involved. This effect is achieved with such programs as Ukrainian Super Top Model (Novyi Kanal), Dances with Stars, and Voice of the Country $(1+1)$. The brand of the Ukrainian Super Top Model show, for example, is promoted at all possible touchpoints (e.g., Facebook, Instagram, YouTube) and this encourages more consumers to join in the interaction, which is mainly the invitation to vote for their favorite participant (see Figures 7 and 8). Other engaging 'hooks' for the audience are video blogs on various topics with experts and the presenter as well as participants' video blogs and their updates aimed at revealing their lives behind the scenes and outside the TV project.

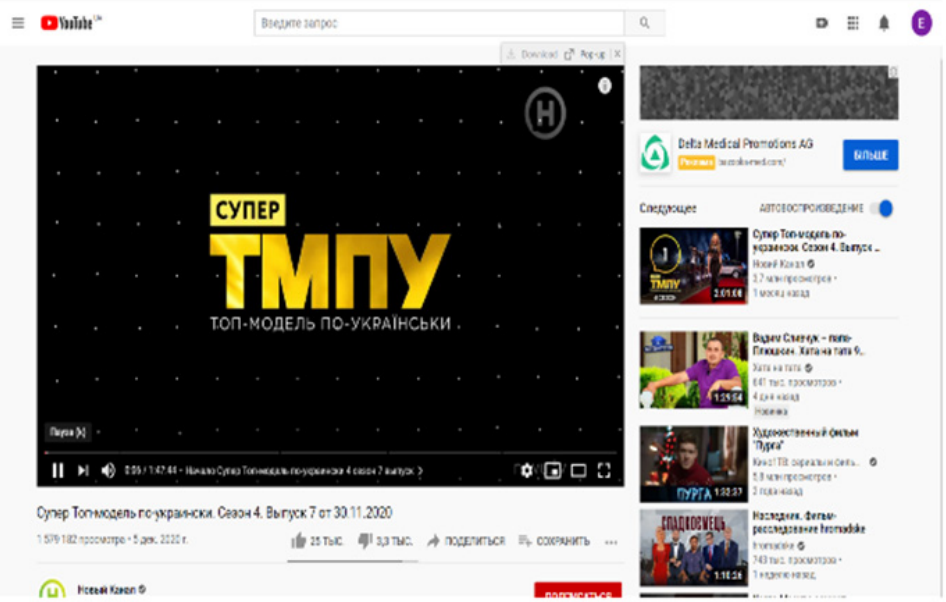

Figure 7: Super Top Model Po-Ukraininsky (Ukrainian Super Top Model) on YouTube.

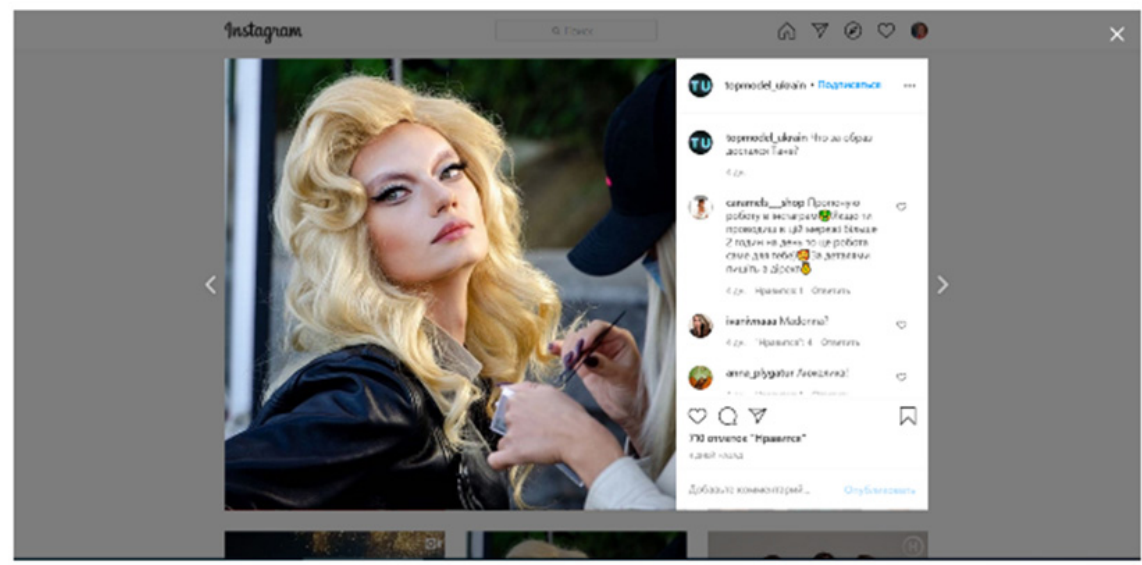

Figure 8: Super Top Model Po-Ukrainsky (Ukrainian Super Top Model) on Instagram. 
Besides, Ukrainian TV channels position themselves as interactive and see communication with their audiences as part of their mission. This message is explicit in their slogans (Let's Live Together (Novyi Kanal), You are not Alone (1+1), Together is Better! (ICTV)). The two-way mode of communication is consistently maintained through responses to the audience's feedback. Novyi Kanal, for example, effectively uses Instagram to keep in touch with their consumers by being constantly online, answering comments on social networks during or between a program's broadcasting time. In their posts, the PR practitioners and journalists maintain the channel's informal register, which contributes to the audience's engagement and affiliation.

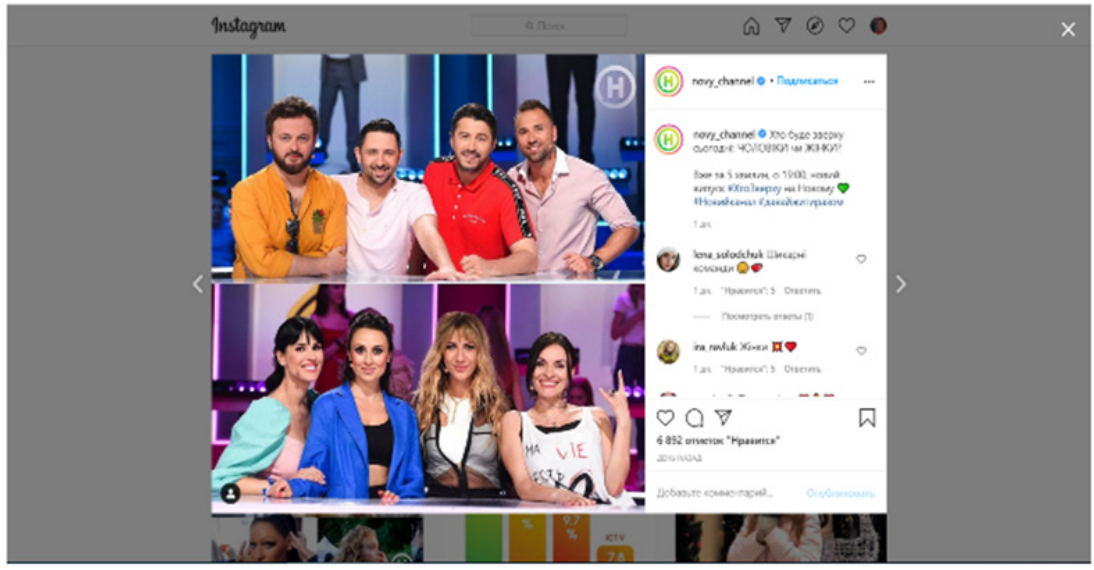

Figure 9: Novyi Kanal interactive page on Instagram.

The sample contains no evidence of the self-reference strategy, i.e., the use of other media as advertising vehicles: the Ukrainian media market is divided between four competing media conglomerates and promoting competitors in these circumstances goes against the common sense. Also, since each group owns multiple media outlets that reach millions of consumers, it is technically more convenient and cost-effective to promote themselves via their own assets. Consequently, the leading TV channels tend to cross-promote their brands and connect with consumers at different times and in different settings through their bundle of multiple channels. Thus, for Ukrainian TV channels, it is cross-promotion that provides added value in terms of contribution into building the groups' image and their brands' strength. Cross-promotion forms of Ukrainian TV channels are tracked in:

- trailers announcing other programs on sister channels (typical of all channels);

- teasers of branded programs on other sister channels (1+1, Inter, STB, Novyi Kanal, 2+2, ICTV);

- divided-screen visual teasers of programs on sister channels (TET, 1+1 ICTV);

- promos of the mother brand (the company) and sister channels and their sub-brands (typical of all channels);

- advertising events organized by sister channels (typical of all channels);

- inviting consumers to participate in different events promoted/organized/sponsored by different sister channels or the company (STB, TET, Inter, $1+1$ );

- inviting audiences to join and engage with the company's digital portfolio of channels or other channels of the group on social media and/or get online broadcast (typical of all channels).

- creating slogans specific to national prominent events or the channel's own events and 
campaigns (Channel Ukraina: a promo for the Children's Day (June 1), videos of the channel's famous hosts that greet with the Independence Day (August 24)).

Another strategy is self-promotion which "refers to the concept of a company advertising itself, that is, its brand(s), programs, titles or products within its own programs or titles" (Siegert, 2008, p. 16). Siegert (2008) sees media promoting their own products as "channels of communications" which require "fewer intermediaries handling the promotional materials" (Ots, 2008, p. 4). The study has revealed the following instruments of self-promotion typical of all Ukrainian TV channels:

- repeated idents between programs and before/after commercials breaks;

- teasers of upcoming programs;

- trailers of daily/weakly programs exclusive on the channel;

- casting selected episodes of series/films/programs broadcast on the channel and inviting viewers to join watching;

- promos and repeated display of the channel's logo before and after commercials to advertise the channel's image and identity and keep it memorable;

- (co)organizing social events by a channel (e.g., charity for the medical workers who face COVID-19) to position the channel's image as socially-responsible and to gain more trust;

- inviting viewers to visit the channel's online sites and pages on social media and engage.

These self-promotion techniques help to put into consumers' minds the channel's image by repeating its logo vocally, visually or both to build an emotional relationship with consumers and, thus, strengthening their trust.

Sponsorship and partnership are another strategy used by Ukrainian TV channels to promote their brands. Though Ukrainian TV channels used to partner or/and sponsor such public events as concerts, national fairs, championships, contests, national or international conferences as well as national films/series and music. The 2020 COVID-19 pandemic, the quarantine and the lockdowns that followed have turned these promotion forms ineffective or, in fact, impossible. Thus, after the arrival of the coronavirus in Ukraine, all Ukrainian media have adjusted their communicative policies to the changes in consumers' priorities and started to position themselves as socially responsible and responsively trustable. Consequently, in 2020, the most notable brand-enhancing sponsorships have been those related to the COVID-19 pandemic.

The leading Ukrainian TV channels have taken it for their mission to raise awareness of COVID-19. As a result, they have made efforts to build their image of responsible national media and a reliable and primary source of information, which enhanced their relationship with consumers and strengthened the consumers' trust and loyalty. Since March, 2020, Ukrainian TV audiences have been exposed to such coronavirus and quarantine-related slogans as, for example, "Take care of yourself and your loved ones": ${ }_{1+1}$ Channel launched a series of social videos urging to be responsible and take care of loved ones in the coronavirus emergency. Other examples of the campaigning are the hashtags like \#StayAtHome (STB), \#BeResponsible $(1+1)$ as well as a number of short videos on STB, ICTV and Novyi Kanal, where famous journalists and hosts explained the quarantine rules to their audiences.

Besides, the leading media groups began competing for launching and featuring charity events. Among these, the most noticeable have been such projects as help to the elderly and pensioners run by Starlight Media Group that owns ICTV, STB, Novy Kanal. In May, 2020, together with the Ukrainian Philanthropic Marketplace, $1+1$ channel, in its turn, launched a music marathon "You Are Not Alone" to raise money to buy personal protective equipment for doctors: the marathon lasted for a week and featured, among other events, an online concert of Ukrainian stars. The viewers were urged to make donations via SMS or the marathon's web page. The first donation arrived from the 1+1 show, Voice of the Country. This may be considered as explicit promotion enforcements: the pandemic was transformed into a means to invite consumers to interact with the channel and, thus, some specific programs got promoted directly. The marathon was an effective way to use the events so as to brand the channel and the emotionally-driven program: the audience, besides interacting with the program, had a chance to show their humanism and participate in the inherently benign 
campaign of helping medical workers on the pandemic frontline. This interactivity was expected to boost the channel's positive image (as well as that of the media group): they positioned themselves as part of the Ukrainian community that offered its help and resources in the emergency.

Some other promotional and branding tools used by the Ukrainian TV channels can be found in public relations: TV channels tend to invite famous actors to host shows or to broadcast their shows (for example, Serhiy Prytula (Novyi Kanal), Yuriy Horbunov (1+1), the comedians from the comedy show Quarter $95(1+1))$, which boosts the channel's attractiveness for the audience.

Along with investments, another technique within this strategy is organizing TV schools for aspiring TV hosts, camera operators, scriptwriters, directors and other TV-related professions (e.g., TeleSchool (Inter)); channels also launch such well-meaning actions as environmental ones (planting trees (Inter)), offer books on certain socially important events or phenomena (e.g., book sales (the site of Inter channel)).

\section{Conclusions and Remarks}

By adopting different branding strategies and promotion activities, the leading Ukrainian TV channels compete to differentiate themselves and their brands. Though the four media groups are controlling Ukraine's media industry and there is no fair competition for other media entries, the necessity to practice marketing activities and branding strategies comes to the fore as the leading channels compete with each other to gain the largest possible share of the audiences.

Building an effectively competitive and strategic branding process, however, is subject to factors such as technological acceleration and investment in technology, market and audience fragmentation, potential changes of legal and regulatory structures, production, competition, marketing and distribution, resource management and response to the changes of the public sphere and audiences' tastes and needs, especially during the pandemic. Due to the oligopolistic competition in the Ukrainian media market, many of these factors are not considered as challenges and, thus, are not taken into account in the TV channels' strategic planning or management efforts. Hence, the branding strategies and their management practices adopted by the Ukrainian TV industry are far from being developed and can be just assessed, from a critical point of view, as only programmed promotional activities rather than a strategic practicability of branding or a long-term systematic process of brand management.

Therefore, the promotional performance of the most popular Ukrainian TV channels controlled by the four leading media companies is almost asymmetric and it is only the level of potency that can rarely make noticeable differences. However, though the companies are competing locally within the media landscape, their promotional and branding practices are effective within this national landscape and they remain the first information and entertainment source for Ukrainian audiences.

\section{References}

Aaker, D. A. (2010). Building strong brands. London, Pocket Books.

Albrecht, E. (2019). In Ukraine's vibrant online media landscape, viability remains a challenge. DW. Retrieved November 15 , 2020, from https://www.dw.com/en/in-ukraines-vibrant-online-media-landscape-viability-remains-a-challenge/ a49062846

Andrusieczko, P. (2019). Media and Politics: 2019 election season. In: Ivanov, V. and Peters, T., B. (Eds.). (2019). Ukrainian Media Landscape - 2019. Konrad-Adenauer-Stiftung Ukraine Office (Kyiv), (pp. 8 - 15). The Academy of Ukrainian Press.

Bourdieu, P. (1986). The Forms of Capital. In J. G. Richardson (Ed.), Handbook of Theory and Research for the Sociology of Education (pp. 241-258). Westport, CT: Greenwood Press.

Budivska, H., \& Orlova, D. (2017). Between Professionalism and Activism: Ukrainian Journalism after the Euromaidan. Kyiv-Mohyla Law and Politics Journal. 3. 137-156. DOI: https://doi.org/10.18523/kmlpj120120.2017-3.137-156 
Burmann C., Piehler R., \& Löwa A. (2015) Strategy Changes, Flexibility and Brand Management. In: Albach H., Meffert H., Pinkwart A., Reichwald R. (Eds.) Management of Permanent Change (pp. 217-240). Springer Gabler, Wiesbaden. https://doi.org/10.1007/978-3-658-05014-6_12

Burmann, C., \& Zeplin, S. (2005). Building brand commitment: A behavioral approach to internal brand management. Journal of Brand Management, 12(4), 279-30o. https://doi.org/10.1057/palgrave.bm.2540223

Calder, B., J. \& Malthouse, E., C. (2008). Media Brands and Consumer Experiences. In Ots, Mart (Ed.). Media Brands and Branding (pp. 89- 93). Jönkoping International Business School, Sweden.

Chaiuk, T. A., Alyeksyeyeva, I. O., Borysovych, O. V., Karpova, K. S., \& Gayevska, O. V. (2021). Celebrities and Microcelebrities in Quarantine: Strategies of Parasocial Communication. Academic Journal of Interdisciplinary Studies, 10(5), 26-44. https://doi.org/10.36941/ajis-2021-0121

Chan-Olmsted, S. (2011). Media branding in a changing world: Challenges and opportunities 2.o. The International Journal on Media Management, 13(1), 3-19. DOI: 10.1080/14241277.2011.568305

Dimitrios, B., Christos, P., Ioannis, R., \& Vasiliadis, L. (2020). Strategic Management in the Hotel Industry: Proposed Strategic Practices to Recover from COVID- 19 Global Crisis. Academic Journal of Interdisciplinary Studies, 9(6), 130-138. https://doi.org/10.36941/ajis-2020-0117

Fernández-Bedoya, V. H., Meneses-La-Riva, M. E., \& Suyo-Vega, J. A. (2021). Ecotourism in Times of Covid-19: A Systematic Review from the Five Continents on How This Activity is Being Carried Out and What Proposals They Have for the Near Future. Academic Journal of Interdisciplinary Studies, 10(6), 1-10. https://doi.org/10.36941/ajis-2021-0148

Fournier, S. (1998). Consumers and Their Brands: Developing Relationship Theory in Consumer Research. Journal of Consumer Research, 24(4), 343-353. doi:10.1086/209515

Gentzkow, M., \& Shapiro, J.M. (2008) Competition and Truth in the Market for News. Journal of Economic Perspectives, 22 (2): 133-154. DOI: 10.1257/jep.22.2.133

Hasaj, A., \& Krymbi, E. (2013). Branding Strategy for Non - Profits in Developing Countries: Case Study Albania. Academic Journal of Interdisciplinary Studies, 2(9), 351-356. Retrieved from https://www.richtmann.org/journal/index.php/ajis/article/view/858

Hoeffler, S., \& Keller, K. L. (2003). The marketing advantages of strong brands. Journal of Brand Management, 10, 421-445. https://doi.org/10.1057/palgrave.bm.2540139

Ivanov, V. (2019). Introduction. In: Ivanov, V. and Peters, T., B. (Eds.). (2019). Ukrainian Media Landscape - 2019. Konrad-Adenauer-Stiftung, Ukraine Office (Kyiv). The Academy of Ukrainian Press. Available on https://www.kas.de/documents/270026/8703904/ENG+KAS+PP+30+Ukrainische+Medienlandschaft2019.pdf/f84e2f58-79ef-3828-b92c-89dbe2160551?version=1.o\&t=1586332596497

Jenkins, H. (2008). Convergence culture: Where old and new media collide. New York University Press. New York.

Keller, K. L. (2013). Strategic brand management. Building, measuring and managing brand equity (4th ed.). Pearson. ISBN: 978-0-13-266425-7

Machmud, M., Irawan, B., Karinda, K., Susilo, J., \& Salahudin. (2021). Analysis of the Intensity of Communication and Coordination of Government Officials on Twitter Social Media during the Covid-19 Handling in Indonesia. Academic Journal of Interdisciplinary Studies, 10(3), 319-334. https://doi.org/10.36941/ajis-20210087

Makki, A., \& Bali, A. O. (2021). The Use of Social Media as a Platform in Education: Ramifications of COVID-19 in Iraq. Academic Journal of Interdisciplinary Studies, 10(3), 394-408. https://doi.org/10.36941/ajis-2021-0093

Malthouse, E, C., \& Schultz, D. (2014) Marketing Communications with Networked Consumers and Negotiated Relationships. In Liu, Y. and Picard, R. G. (Eds.), Policy and Marketing Strategies for Digital Media (pp. 233245). Routledge, New York.

McDowell, W. S. (2005). Selling the niche: a qualitative content analysis of cable network business-to-business advertising, The International Journal on Media Management, 6(3\&4): 217-225.

McDowell, W. S. (2006 a). Confrontation or conciliation? The plight of small media brands in a zero sum marketplace, Journal of Media Business Studies, 3(2):1-22. DOI: 10.1080/16522354.2006.11073439

McDowell, W. S. (2006 b). Issues in marketing and branding. In A. B. Albarran \& S. M. Chan- Olmsted (Eds.), Handbook of media management and economics (pp. 229-250). Mahwah, NJ: Lawrence Erlbaum.

McDowell, W. S. (2011). The brand management crisis facing the business of journalism. International Journal on Media Management, 13(1), 37-51. 10.1080/14241277.2010.545364

McDowell, W. S., \& Sutherland, J. (200o). Choice versus chance: using brand equity theory to explore audience inheritance effects, a case study, Journal of Media Economics, 13: 233-247. DOI: 10.1207/S15327736ME1304_3

Moroz, O. V., Karachyna, N. P., Vakar, T. V., \& Vitiuk, A. V. (2020). Territorial Branding as an Instrument for Competitiveness of Rural Development. Academic Journal of Interdisciplinary Studies, 9(3), 166-175. https://doi.org/10.36941/ajis-2020-0052 
Mostafa, B. A., El-Borsaly, A. A.-E., Hafez, E. A.-E., \& Hassan, S. A. (2021). The Mediating Effect of PersonOrganization Value Fit on the Relationship Between University branding and Academic Staff Citizenship Behavior. Academic Journal of Interdisciplinary Studies, 10(1), 313-326. https://doi.org/10.36941/ajis-2021-0027

Müller, H. (2017). Populism, De-Globalization, and Media Competition: The Spiral of Noise. Central European Journal of Communication, vol. 10, no. 1/18, pp. 64-78. Doi:10.19195/1899-5101.10.1(18).5.

National Council of Television and Radio Broadcasting of Ukraine. (n.d.). Reports. [Official website]. Retrieved from https://www.nrada.gov.ua/reports/

Nielsen, R., Cornia, A., \& Kalogeropoulos, A. (2016). Challenges and Opportunities for News Media and Journalism in an Increasingly Digital, Mobile, and Social Media Environment. Reuters Institute for the Study of Journalism, Council of Europe Report DGI (2016) 18.

Nielson, R.K. (2016). The business of news. In: Witschge, T., Anderson, C.W., Domingo, D. and Hermida, A.(Eds.), The Sage Handbook of Digital Journalism (pp. 51-67). Newbury Park, CA: Sage.

Nikitina, T. (2020) The Ukrainian Media Landscape. In: Veira-Ramos A., Liubyva T., Golovakha E. (Eds.) Ukraine in Transformation, (pp. 167- 201). Palgrave Macmillan, Cham. https://doi.org/10.1007/978-3-030-24978-6_8

Ocheni, S. I., Agba, A. M. O., Agba, M. S., \& Eteng, F. O. (2020). Covid-19 and the Tourism Industry: Critical Overview, Lessons and Policy Options. Academic Journal of Interdisciplinary Studies, 9(6), 114-129. https://doi.org/10.36941/ajis-2020-0116

Ots, M. (2008). Media and Brands: New Ground to Explore. In Ots, M. (Ed.). Media Brands and Branding (pp. 1- 7). Jönkoping International Business School, Sweden.

Ots, M., \& Wolff, P. (20o8). Media Consumer Brand Equity: Implications for Advertising Media Planning. In Ots, Mart (Ed.). Media Brands and Branding (pp. 95- 112). Jönkoping International Business School, Sweden.

Ots, M., \& Wolff, P. -E. (20o8). Media consumer brand equity: Implications for advertising media planning. In Ots, M. (Ed.), Media brands and branding (pp. 95-112). Jönköping: Jönköping International Business School.

Riezebos, H., Kist, B., \& Kootstra, G. (2002). Brand management: A theoretical and practical approach. Harlow; New York: Financial Times Prentice Hall.

Rohn, U. (2015) International Media Branding. In: Siegert, G., Förster, K., Chan-Olmsted, S. \& Ots, M. (Ed.) Handbook of Media Branding (pp 81-95). Springer, Cham. https://doi-org443.webvpn.jnu.edu.cn/10.1007/978-3-319-18236-0_16

Rusi, N., \& Shqarri, F. (2020). Limitation or Derogation? The Dilemma of the States in Response to Human Rights Threat during the COVID-19 Crisis. Academic Journal of Interdisciplinary Studies, 9(5), $166-176$. https://doi.org/10.36941/ajis-2020-0095

Russ-Mohl, S., \& Nazhdiminova, R. (2015). Media Branding and Media Marketing: Conflicts with Journalistic Norms, Risks of Trial and Error. In: Siegert, G., Förster, K., Chan-Olmsted, S. \& Ots, M. (Eds), Handbook of Media Branding (pp. 337- 353). Springer, Cham. https://doi.org/10.1007/978-3-319-18236-o_2

Ryabinska, N. (2011). The Media Market and Media Ownership in Post-Communist Ukraine. Problems of PostCommunism. 58. 3-20. DOI: 10.2753/PPC1075-8216580601

Schultz, D. E., Block, M. P., \& Viswanathan, V. (2014). Brand preference being challenged. Journal of Brand Management, 21(5), 408 428. https://doi.org/10.1057/bm.2014.5

Siegert, G. (2008). Self Promotion: Pole Position in Media Brand Management. In Ots, Mart (Ed.). Media Brands and Branding (pp. 11- 26). Jönkoping International Business School, Sweden.

Siegert, G., Förster, K., Chan-Olmsted, S.M., \& Ots, M. (2015) What Is So Special About Media Branding? Peculiarities and Commonalities of a Growing Research Area. In: Siegert G., Förster K., Chan-Olmsted S. and Ots M. (Eds.) Handbook of Media Branding (pp. 1-8). Springer, Cham. https://doi-org443.webvpn.jnu.edu.cn/10.1007/978-3-319-18236-0_16

Sommer, C. (2015). Media brands and the advertising market: Exploring the potential of branding in media organizations' b2b relationships. In Siegert G., Förster K., Chan-Olmsted S. and Ots M. (Eds.), Handbook of media branding (pp. 102-115). Berlin: Springer.

Sommer, Ch. \& Marty, L. (2015). The role of media brands in media planning. Journal of Media Business Studies, 12(3):185-203. DOI: https://doi.org/10.1080/16522354.2015.10700877

Television Industry Committee (n.d.). Top Channels. TV PANEL, Ratings. Retrieved from http://tampanel.com.ua /en/ratings/

Thompson, K., \& Strutton, D. (2012). Revisiting perceptual fit in co-branding applications. Journal of Product $\mathcal{E}$ Brand Management, 21(1), 15-25. https://doi.org/10.1108/10610421211203079

USAID-Internews 2020 Media Consumption Survey. (2020). Retrieved from https://internews.org/sites/default /files/2020-10/2020-Media-Consumption-Survey-FULL-FIN-Eng.pdf

Weinacht, S. (2015) Marketing Communication of Media Brands: A Literature Review. In: Siegert G., Förster, K., Chan-Olmsted, S. and Ots, M. (Eds) Handbook of Media Branding. Springer, Cham. https://doi-org443.webvpn.jnu.edu.cn/10.1007/978-3-319-18236-o_166 